\title{
PERBANDINGAN PENDAPATAN ANTARA TERNAK SAPI ONGOLE YANG MENGGUNAKAN IB DAN KAWIN ALAM DI DESA TEMPOK KECAMATAN TOMPASO
}

\author{
Octavianus C. M. Phun, B Rorimpandey*, M. A. V. Manese, S. J. K. Umboh \\ Fakultas Peternakan Universitas Sam Ratulangi Manado, 95115
}

\begin{abstract}
ABSTRAK
Penelitian ini bertujuan untuk mengetahui perbedaan pendapatan peternak sapi potong yang melakukan program Inseminasi Buatan (IB) dan yang melakukan kawin alam di Desa Tempok Kecamatan Tompaso Kabupaten Minahasa. Penelitian dilakukan selama satu bulan, mulai tanggal 19 Agustus 19 September 2019. Lokasi penelitian dipilih karena sebagian besar peternak telah mengikuti program IB. Jumlah responden 30 orang peternak sapi yang menggunakan IB, dan 30 responden peternak sapi yang menggunakan kawin alam. Sumber data yang digunakan yaitu data primer dan data sekunder. Data diolah secara distribusi frekuensi dan dianalisa secara deskriptif kuantitatif menggunakan teknik regresi linier berganda. Hasil yang diperoleh dari penelitian ini adalah pendapatan peternak sapi yang melakukan IB lebih rendah dari pada peternak yang melakukan kawin alam yaitu Rp. 17.369.096,67/peternak per tahun sedangkan yang menggunakan sistim inseminasi Rp.13.947.153,33/peternak per tahun tetapi secara statistic tidak berbeda nyata $(\mathrm{P}>0,05)$.
\end{abstract}

Kata Kunci : Kawin IB, kawin alam, pendapatan ternak sapi.

Korespondensi (corresponding author) Email: rorimpandeyboyke@ymail.com

ABSTRACT
COMPARISON OF INCOMES
BETWEEN
MAINTAINING CATTLE ONGOLE
BREEDING USING ARTIFICIAL
INSEMINATION AND BREEDING
USING NATURAL MATING AT
TEMPOK VILLAGE OF TOMPASO
DISTRICT. Study was done to evaluate
incomes of household farmers
maintaining beef cattle breeding using
artificial insemination and beef cattle
breeding using natural mating at Tempok
village of Tompaso district, Minahasa
regency. Study was started on August 19
to September 19 2019. The respondents
of household involving in this study were
30 farmers using the artificial
insemination in animal breeding and 30
farmers using using natural mating in
animal breeding. Data were collected
from primer and secondary sources. Data
were analyzed using technical multiple
regression of theCobb-Douglas model.
The result showed that incomes of
household farmers applying the artificial
insemination in animal breeding were
lower than those of household farmers
applying the natural mating in animal
breeding with the average of IDR
13,947,153.33 per farmer per year,
compared with those of IDR
17,369,096.67 per farmer per year,
respectively but statistically not
significant (P>0,05)

ABSTRACT

COMPARISON OF INCOMES

MAINTAINING CATTLE ONGOLE BREEDING USING ARTIFICIAL INSEMINATION AND BREEDING USING NATURAL MATING AT TEMPOK VILLAGE OF TOMPASO DISTRICT. Study was done to evaluate incomes of household farmers maintaining beef cattle breeding using artificial insemination and beef cattle breeding using natural mating at Tempok regency. Study was started on August 19 to September 19 2019. The respondents of household involving in this study were insemination in animal breeding and 30 farmers using using natural mating in animal breeding. Data were collected from primer and secondary sources. Data were analyzed using technical multiple The result showed that incomes of household farmers applying the artificial insemination in animal breeding were applying the natural mating in animal breeding with the average of IDR $13,947,153.33$ per farmer per year, $17,369,096.67$ per farmer per year, respectively but statistically not ignificant $(\mathrm{P}>0,05)$ 
Keywords: Artificial insemiantion, natural mating, beef catlle income.

\section{PENDAHULUAN}

Sub sektor peternakan memiliki peran penting dalam penyediaan protein hewani, lapangan kerja, pengentasan kemiskinan, dan pengembangan potensi wilayah. Peran penting ini diharapkan menjadi sumber pendapatan peternak dan memberikan kontribusi terhadap pemenuhan kebutuhan keluarga peternak. berkisar antara Rp. 201.666,67 sampai dengan Rp. 113.777,78 per tahun.

Monintja et al. (2015) dalam penelitian mengenai keuntungan peternakan sapi Peranakan Ongole (PO) yang menggunakan Inseminasi Buatan (IB) di Kecamatan Tompaso Barat menunjukkan bahwa keuntungan dari selisih antara penerimaan dan penjualan ternak hasil IB dan total biaya adalah sekitar Rp. 21.504.250 dan untuk ratarata pendapatan atau keuntungan yang didapat dari 30 responden yang menggunakan IB di Tompaso Barat yaitu berkisar Rp. 716.808. Hal ini juga sejalan dengan penelitian Sugiarto dan Siregar (1998) bahwa Inseminasi Buatan memberikan dampak yang nyata terhadap peningkatan pendapatan.
Desa Tempok Kecamatan Tompaso merupakan salah satu desa dengan peternak sapi yang cukup banyak yaitu 102 peternak. Rata-rata kepemilikan ternak 4-12 ekor per peternak sapi dan merupakan salah satu desa yang mengikuti program SIWAB (Sapi Induk Wajib Bunting) dengan menggunakan IB, namun sebagian besar peternak yang pernah menggunakan IB beralih menggunakan kawin alam. Padahal hasil penelitian Hastuti et al., (2008), bahwa pendapatan hasil inseminasi buatan lebih tinggi dari pada kawin alam, jika peternak melihat dari sisi biaya produksi. Fenomena ini menjadi menarik untuk dikaji yaitu perbedaan pendapatan yang diperoleh peternak sapi Ongole yang menggunakan IB dan kawin alam, serta faktor-faktor apa yang mempengaruhi pendapatan peternak sapi Ongole di Desa Tempok.

\section{METODE PENELITIAN}

\section{Tempat dan Waktu Penelitian}

Penelitian ini dilaksanakan di Desa Tempok Kecamatan Tompaso Kabupaten Minahasa. Penelitian dilaksanakan selama satu bulan, tanggal 19 Juni - 19 Juli 2019. 


\section{Penentuan Lokasi Penelitian}

Penentuan Desa ini secara purposive dengan pertimbangan jumlah populasi ternak sapi terbanyak di Kecamatan Tompaso dan terdapat usaha pemeliharaan ternak sapi dengan menggunakan Inseminasi Buatan dan menggunakan kawin alam.

\section{Penentuan Responden}

Jumlah peternak sapi di Desa Tempok Kecamatan Tompaso Kabupaten Minahasa sebanyak 102 peternak. Peternak yang pernah menggunakan IB sebanyak 72 peternak dan menggunakan kawin alam sebanyak 30 peternak. Peternak yang menggunakan IB diambil 30 peternak yang dijadikan responden diambil menggunakan simple random sampling atau pengambilan sampel acak, sedangkan peternak yang menggunakan kawin alam sebanyak 30 peternak semuanya dijadikan responden (sensus). Sampel responden ditetapkan mengikuti Sugiyono dalam Monintja (2015), yang menyatakan berapa pun jumlah populasinya dalam penelitian sosial ukuran sampel yang layak digunakan antara 30-500 orang.

\section{Pengambilan Data}

Jenis data yang dikumpulkan yaitu data primer dan sekunder. Data primer diperoleh dari hasil wawancara langsung dengan responden ternak sapi Ongole yang menggunakan IB dan yang menggunakan kawin alam melalui kuesioner di Desa Tempok Kecamatan Tompaso. Data primer yang dikumpulkan seperti jenis pakan apa yang diberikan, biaya obat-obatan, biaya tenaga kerja dan lain-lain. Data sekunder diperoleh dari instansi-instansi terkait, seperti pejabat-pejabat Desa Tempok dan kantor dinas P3K yang ada di Kecamatan Tompaso.

\section{Analisis Data}

Untuk mengestimasi faktor-faktor yang mempengaruhi pendapatan ternak sapi yang menggunakan IB dan yang menggunakan kawin alam, digunakan regresi linier berganda sebagai berikut (Gupito et al., 2014):

$$
Y=a+b 1 X 1+b 2 X 2+b 3 X 3+b 4 X 4
$$

Keterangan :

$\mathrm{Y}=$ Pendapatan peternak sapi (Rp/tahun)

$\mathrm{X} 1$ = Biaya pakan (Rp/tahun)

$\mathrm{X} 2$ = Biaya obat-obatan (Rp/tahun) 
$\mathrm{X} 3$ = Biaya tenaga keluarga $(\mathrm{Rp} /$ tahun $)$

$\mathrm{X} 4$ = Biaya IB / biaya sewa pejantan (Rp/tahun)

Uji t (t-test) dilakukan untuk pengujian signifikansi dari setiap koefisien regresi variabel bebas secara parsial dengan mengasumsikan bahwa variabel bebas lainnya dianggap konstan. (Sugiyono, 2014).

Uji F menurut Rochaeni et al. (2014) adalah untuk mengetahui pengaruh variabel bebas secara bersama sama terhadap variabel terkait. Bila nilai $\mathrm{F}$ yang di hitung lebih besar dari nilai $\mathrm{F}$ tabel maka berarti secara keseluruhan variabel bebas pengaruh nyata terhadap variabel tidak bebas.

Untuk menganalisis pendapatan rata-rata dari peternak yang menggunakan IB dan yang menggunakan kawin alam digunakan uji beda dua ratarata dengan teknik uji $t$ dua sampel tidak berpasangan (Soelistyo, 2011). Metode analsisis tersebut digunakan untuk menguji apakah terdapat perbedaan yang nyata secara statistik pada pendapatan ternak sapi yang menggunakan IB dan yang menggunakan kawin alam. Untuk melakukan uji $t$ dua sampel tidak berpasangan maka perlu diuji apakah bersifat normal dan data memiliki varians yang homogen.

Jika hasil pengujian menunjukkan bahwa data bersifat normal dan homogen, maka untuk menguji hipotesis digunakan uji $\mathrm{t}$ dengan rumus $\mathrm{t}$ hitung sebagai berikut (Hasibuan, 2014) :

$$
\text { thitung }=\frac{\overline{\mathrm{x}}_{1}-\overline{\mathrm{x}}_{2}}{\sqrt{\frac{\left(n_{1}-1\right) \mathrm{S}_{1}{ }^{2}\left(n_{2}-1\right) S_{2}^{2}}{n_{1}+n_{2}-2}}\left(\frac{1}{\mathrm{n}_{1}}+\frac{1}{\mathrm{n}_{2}}\right)}
$$

\section{Keterangan:}

$\mathrm{X}_{1}=$ Rata-rata variabel 1 (pendapatan usaha ternak sapi potong sistem IB)

$\mathrm{X}_{2}=$ Rata-rata variabel 2 (pendapatan usaha ternak sapi potong sistem kawin alam)

$S_{1}=$ Varian sampel variabel 1 (pendapatan usaha ternak sapi potong sistem IB)

$\mathrm{S}_{2}=$ Varian sampel variabel 2 (pendapatan usaha ternak sapi potong sistem kawin alam)

$\mathrm{n}_{1}=$ Jumlah sampel variabel 1 (pendapatan usaha ternak sapi potong sistem IB)

$\mathrm{n}_{2}=$ Jumlah sampel variabel 2 (pendapatan usaha ternak sapi potong sistem kawin alam)

Dengan kriteria uji : Jika t-hitung $\leq$ t-tabel, maka $\mathrm{H}_{0}$ ditolak dan $\mathrm{H}_{1}$ diterima (ada perbedaan antara 
pendapatan usaha ternak sapi yang menggunakan IB dan yang menggunakan kawin alam). Jika t-hitung $\geq$ t-tabel, maka $\mathrm{H}_{0}$ diterima dan $\mathrm{H}_{1}$ ditolak (tidak ada perbedaan antara pendapatan usaha ternak sapi sistem IB dan kawin alam) (Sugiyono, 2006).

\section{Karakteristik Responden}

Umur, Tingkat Pendidikan, Jenis Pekerjaan

Peternak yang dijadikan responden dalam penelitian ini adalah peternak yang masih tergolong peternak sapi tradisional, hal ini dikemukakan (Nurcholida et al., 2013) bahwa 90 persen usaha ternak sapi dilaksanakan secara tradisional oleh petani di pedesaan, usaha ternak sapi yang demikian dikategorikan sebagai peternakan rakyat. Unsur karakteristik yang dikumpulkan dari responden antara lain umur, tingkat pendidikan dan jenis pekerjaan. Data karakteristik dapat dilihat pada Tabel 1. Umur peternak sapi kawin alam 38-50 tahun yaitu sebanyak 18 orang, dan untuk peternak yang berusia diatas 50 tahun sebanyak 12 orang. Untuk peternak sapi pengguna IB berumur 38 - 50 tahun sebanyak 20 orang dan lebih dari 50 tahun berjumlah 10 orang. Peternak yang menggunakan IB dan kawin alam yang berumur 38-50 tahun tergolong dalam usia produktif sedangkan peternak IB dan kawin alam yang berusia 50 tahun keatas tergolong sudah tidak produktif (Dewandini, 2010. Pada umumnya responden yang berusia produktif memiliki semangat yang tinggi dalam menggembangkan usaha tani. (Harmanto, 1996) mengatakan bahwa tingkat produktif seseorang yaitu pada usia antara 15-55 tahun sedangkan umur yang tidak produktif berada di bawah 15 tahun dan diatas 55 tahun.

Tabel 1 menunjukan pendidikan yang dimiliki oleh peternak sapi di Desa Tempok yang menggunakan kawin alam yang dijadikan responden, tingkat pendidikan SD berjumlah 10 orang, SMP berjumlah 6 orang, dan SMA berjumlah 14 orang, sedangkan untuk peternak sapi IB, tingkat pendidikan SD 6 orang, SMP 7 orang, dan SMA 17 orang. Kiswanto et al. (2004) mengemukakan bahwa tingkat pendidikan yang makin tinggi memungkinkan dapat mengubah sikap dan perilakunya untuk bertindak lebih rasional. Pekerjaan utama responden sesuai pada Tabel 1, paling banyak adalah jenis pekerjaan sebagai petani. 
Tabel 1. Karakteristik Responden Peternak Sapi di Desa Tempok Kecamatan Tompaso

\begin{tabular}{lllll}
\hline No. & Peternak KA & Orang & Peternak IB & Orang \\
\hline 1 & Umur (Tahun) & & Umur (Tahun) & \\
& $38-50$ & 18 & $37-50$ & 20 \\
& $>50$ & 12 & $>50$ & 10 \\
\hline \multicolumn{2}{l}{ Jumlah } & $\mathbf{3 0}$ & Jumlah & $\mathbf{3 0}$ \\
\hline \multirow{2}{*}{2} & Tingkat & & & \\
& Pendidikan & & Tingkat Pendidikan & \\
& SD & 10 & SD & 6 \\
& SMP & 6 & SMP & 7 \\
& SMA & 14 & SMA & 17 \\
\hline & Jumlah & $\mathbf{3 0}$ & Jumlah & $\mathbf{3 0}$ \\
\hline 3 & Jenis Pekerjaan & & Jenis Pekerjaan & 27 \\
& Petani & 25 & Petani & 1 \\
& PNS & 3 & PNS & 2 \\
\hline & Pensiunan & 2 & Pensiunan & $\mathbf{3 0}$ \\
\hline & Jumlah & $\mathbf{3 0}$ & Jumlah &
\end{tabular}

Biaya Produksi

Biaya produksi merupakan biaya

yang dikeluarkan oleh petani peternak / selama kegiatan usaha ternak berlangsung hingga menghasilkan produk. Untuk pengeluaran biaya produksi bisa dilihat pada Tabel 2 .

Tabel 2. Perbedaan Biaya Produksi Peternak Sapi Potong IB dan Kawin Alam

\begin{tabular}{llrlr}
\hline No & Peternak Sapi KA & $\begin{array}{l}\text { Jumlah } \\
(\mathbf{R p})\end{array}$ & Peternak Sapi IB & \multicolumn{2}{l}{$\begin{array}{l}\text { Jumlah } \\
(\mathbf{R p})\end{array}$} \\
\hline 1 & Biaya Pakan & 743.884 .600 & Biaya Pakan & 702.829 .400 \\
2 & Biaya Penyusutan & 3.930 .000 & Biaya Penyusutan & 3.711 .000 \\
& Kandang & & Kandang & \\
3 & Biaya Tenaga Kerja & 1.912 .500 & Biaya Tenaga Kerja & 1.825 .000 \\
4 & Biaya Sewa Lahan & 6.050 .000 & Biaya Sewa Lahan & 5.850 .000 \\
5 & Biaya Obat & 1.450 .000 & Biaya Obat & 1.380 .000 \\
6 & Sewa Pejantan & 5.700 .000 & Biaya IB & 1.390 .000 \\
\hline & Total Biaya & $\mathbf{7 6 2 . 9 2 7 . 1 0 0}$ & Total Biaya & $\mathbf{7 1 6 . 9 8 5 . 4 0 0}$ \\
\hline
\end{tabular}


Berdasarkan Tabel 2, biaya pakan merupakan biaya paling tinggi dalam biaya produksi, yaitu sebesar Rp. 743.884.600/tahun untuk peternakan sapi kawin alam, sedangkan untuk biaya pakan peternak sapi IB Rp. 702.829.400/tahun. Hal ini sejalan dengan penelitian Otampi et al. (2017), bahwa biaya pakan adalah biaya terbesar pada usaha sapi. Untuk biaya produksi lainnya bervariasi.

\section{Penerimaan}

Penerimaan diperoleh dari hasil penjualan ternak sapi satu tahun sebelum penelitian (Aiba et al., 2018). Penerimaan diperhitungkan hanya dalam

\begin{tabular}{llcrr}
\hline No & Peternakan Sapi KA & $\begin{array}{c}\text { Jumlah } \\
\text { (Rp/Thn) }\end{array}$ & Peternakan Sapi IB & $\begin{array}{c}\text { Jumlah } \\
(\mathbf{R p} / \text { Thn })\end{array}$ \\
\hline 1 & $0-6$ bulan & 109.500 .000 & $0-6$ bulan & 82.000 .000 \\
2 & $7-12$ bulan & 203.500 .000 & $7-12$ bulan & 151.900 .000 \\
3 & $1-3$ tahun & 349.500 .000 & $1-3$ tahun & 371.000 .000 \\
4 & $>3-5$ tahun & 395.500 .000 & $>3-5$ tahun & 33.200 .0000 \\
5 & $>5$ tahun & 226.000 .000 & $>5$ tahun & 198.500 .000 \\
\hline & Total & $\mathbf{1 . 2 8 4 . 0 0 0 . 0 0 0}$ & Total & $\mathbf{1 . 1 3 5 . 4 0 0 . 0 0 0}$ \\
\hline
\end{tabular}

Tabel 4. Perbedaan Jumlah Pendapatan Peternak Sapi Kawin Alam dan IB.

\begin{tabular}{llrrr}
\hline Peternakan Sapi & $\begin{array}{l}\text { Jumlah } \\
\text { No }\end{array}$ KA & Rp/Thn) $)$ & Peternakan Sapi IB & $\begin{array}{l}\text { Jumlah } \\
(\mathbf{R p} / \text { Thn) })\end{array}$ \\
\hline 1 & Total Penerimaan & 1.284 .000 .000 & Total Penerimaan & 1.135 .400 .000 \\
2 & Total Biaya Produksi & 762.927 .100 & Total Biaya Produksi & 716.985 .400 \\
\hline 3 & Total Pendapatan & 521.072 .900 & Total Pendapatan & 418.414 .600 \\
\hline 4 & Rata-rata Pendapatan & $17.369 .096,67$ & Rata-rata Pendapatan & $13.947 .153,33$ \\
\hline
\end{tabular}




\section{Pendapatan}

Pendapatan diperoleh dari seluruh penerimaan dari usaha ternak sapi dikurangi dengan biaya produksi. Siswandari et al. (2013) menyatakan bahwa setiap peternak memiliki tingkatan pendapatan yang berbeda-beda. Menurut hasil analisis Tabel 4 menunjukkan bahwa peternakan sapi sistim kawin alam di desa Tempok selama satu tahun memperoleh pendapatan sebanyak Rp. 521.072.900, dengan rata-rata pendapatan sebanyak Rp. 17.369.096,67 /tahun/peternak. Untuk peternak sapi IB memperoleh pendapatan sebesar Rp. 418.414.600/tahun, dengan rata-rata pendapatan peternak sebanyak Rp. 13.947.153,33/tahun/peternak. Hasil ini sejalan dengan penelitian Sirajudin (2013), bahwa pendapatan peternak sapi yang menggunakan kawin alam lebih besar dari pada pendapatan peternak yang menggunakan IB.

\section{Hasil Uji Perbedaan Pendapatan Ternak Sapi yang menggunakan IB dan Kawin Alam}

Nilai signifikansi yang diperoleh adalah 0,173, dengan demikian dapat disimpulkan bahwa kelompok data memiliki varian yang berbeda $(0,173>0,05)$. Nilai $\mathrm{T}$ hitung adalah 1,381 dan nilai $\mathrm{T}$ tabel adalah 2,002. Jika $\mathrm{T}$ hitung $<\mathrm{T}$ tabel, maka $\mathrm{H}_{0}$ diterima dan $\mathrm{H}_{1}$ ditolak, artinya pendapatan usaha ternak sapi yang menggunakan IB, dan pendapatan usaha ternak sapi yang menggunakan kawin alam berbeda tidak nyata

\section{Faktor-faktor Yang Mempengaruhi Produksi Ternak Sapi yang menggunakan IB}

Penelitian menggunakan metode regresi linier berganda dalam menguji hipotesis yang diajukan dengan program komputer SPSS 22. Hasil analisis pada Tabel 5 diperoleh persamaan regresi sebagai berikut:

$$
\begin{gathered}
Y=6653-0,445 X_{1}-70,597 X_{2}- \\
131,303 X_{3}-669,25 X_{4}
\end{gathered}
$$

Hasil analisis menunjukkan bahwa koefisien determinasi untuk model ini adalah 0,694. Artinya bahwa $69,4 \%$ pendapatan peternak sapi yang menggunakan IB dipengaruhi oleh biaya pakan, biaya obat-obatan, biaya tenaga kerja, sedangkan $30,6 \%$ sisanya dipengaruhi oleh faktor-faktor lain yang tidak dapat dijelaskan. 
Tabel 5. Analisis Regresi Ternak Sapi yang menggunakan IB

\begin{tabular}{|c|c|c|c|}
\hline Variabel & Koefisien & T hitung & Prob \\
\hline Constanta & 6653 & 6,14 & 0,000 \\
\hline Biaya pakan & $-0,445$ & $-1,933$ & 0,065 \\
\hline Biaya obat & $-70,597$ & $-1,476$ & 0,153 \\
\hline Biaya tenaga kerja & $-131,303$ & $-1,654$ & 0,111 \\
\hline $\begin{array}{l}\text { Inseminasi buatan } \\
\text { F hitung }\end{array}$ & $-669,25$ & $-2,459$ & $\begin{array}{l}0,021 \\
0.000\end{array}$ \\
\hline Ajusted R2 & & & 0,694 \\
\hline
\end{tabular}

Tabel 5 menunjukkan hasil uji pengaruh variabel secara serempak dengan menggunakan Uji F menunjukkan bahwa nilai signifikansi $\mathrm{F}$ adalah sebesar $(0,000)$. Nilai yang diperoleh lebih kecil dari probabilitas kesalahan yang ditolerir, yaitu $\alpha 5 \%$ atau 0,05. Hal ini menunjukkan bahwa, biaya pakan $\left(\mathrm{X}_{1}\right)$, biaya obat-obatan $\left(\mathrm{X}_{2}\right)$, biaya tenaga kerja $\left(\mathrm{X}_{3}\right)$, inseminasi buatan $\left(\mathrm{X}_{4}\right)$ secara serentak, berpengaruh nyata terhadap jumlah produksi ternak sapi yang menggunakan IB (Y). Untuk pengaruh setiap variabel secara parsial dapat dilihat bahwa variabel $\mathrm{X}_{1}$ biaya pakan memiliki nilai t-hitung sebesar $1,933<$ nilai t-tabel $2,059, \mathrm{X}_{2}$ biaya obatobatan memiliki nilai t-hitung 1,476< nilai t-tabel 2,059, $\mathrm{X}_{3}$ biaya tenaga kerja memiliki nilai t-hitung $1,654<$ nilai $t$ - tabel 2,059, hal ini menunjukan tidak terdapat pengaruh yang signifikan tehadap pendapatan sapi yang menggunakan IB, sedangkan untuk variabel $\mathrm{X}_{4}$ biaya inseminasi buatan memiliki nilai t-hitung 2,459> nilai ttabel 2,059, hal ini menunjukan bahwa terdapat pengaruh terhadap pendapatan sapi yang menggunakan IB.

\section{Faktor-faktor Yang Mempengaruhi Produksi Ternak Sapi Yang Menggunakan Kawin Alam}

Penelitian menggunakan metode regresi linier berganda dalam menguji hipotesis yang diajukan dengan program komputer SPSS 22. 
Tabel 6. Analisis Regresi Ternak Sapi yang Menggunakan Kawin Alam

\begin{tabular}{lrrr}
\hline Variabel & Koefisien & t hitung & Prob \\
\hline Constanta & 6877 & 3,365 & 0,004 \\
Biaya pakan & $-1,214$ & $-4,070$ & 0,001 \\
Biaya obat & 186,448 & 2.49 & 0,025 \\
Biaya tenaga kerja & $-148,669$ & $-1,299$ & 0,214 \\
Sewa pejantan & $-78,707$ & $-0,993$ & 0,337 \\
F hitung & & & 0,000 \\
Ajusted R2 & & & 0,699 \\
\hline
\end{tabular}

Hasil analisis diperoleh persamaan regresi sebagai berikut:

\section{$Y=6877-1,214 X_{1}+186,448 X_{2}-$ $148,669 X_{3}-78,707 X_{4}$}

Hasil analisis pada Tabel 6 menunjukkan bahwa koefisien determinasi untuk model ini adalah 0,699. Artinya bahwa $69,9 \%$ pendapatan peternak sapi yang menggunakan kawin alam dipengaruhi oleh biaya pakan, biaya obat, biaya tenaga kerja dan sewa pejantan. Sedangkan $30,1 \%$ sisanya dipengaruhi oleh faktor-faktor lain yang tidak dapat dijelaskan dalam model ini.

Hasil uji pengaruh variabel secara serempak dengan menggunakan Uji $\mathrm{F}$ menunjukkan bahwa nilai signifikansi $\mathrm{F}$ adalah sebesar (0,000). Nilai yang diperoleh lebih kecil dari probabilitas kesalahan yang ditolerir, yaitu $\alpha 5 \%$ atau
0,05. Hal ini menunjukkan bahwa, biaya pakan $\left(\mathrm{X}_{1}\right)$, biaya obat $\left(\mathrm{X}_{2}\right)$, biaya tenaga kerja $\left(\mathrm{X}_{3}\right)$, sewa pejantan $\left(\mathrm{X}_{4}\right)$ secara serentak, berpengaruh nyata terhadap jumlah pendapatan ternak sapi yang menggunakan kawin alam (Y).

Pengaruh setiap variabel secara parsial dapat dilihat bahwa variable biaya pakan ( $\left.\mathrm{X}_{1}\right)$ memiliki nilai t-hitung sebesar 4,070> nilai t-tabel 2,059, $\mathrm{X}_{2}$ biaya obat-obatan memiliki nilai t-hitung 2.49> nilai t-tabel 2,059, hal ini menunjukan $\mathrm{X}_{2}$ biaya obat mempunyai pengaruh signifikan tehadap produksi sapi yang menggunakan kawin alam. Untuk variabel $\mathrm{X}_{3}$ biaya tenaga kerja memiliki nilai t-hitung $1,299<$ nilai $\mathrm{t}$ tabel 2,059, $\mathrm{X}_{4}$ sewa pejantan memiliki nilai t-hitung $0,993<$ nilai t-tabel 2,059, hal ini menunjukan bahwa $\mathrm{X}_{4}$ sewa sapi pejantan tidak berpengaruh signifikan 
terhadap pendapatan sapi yang menggunakan kawin alam.

\section{KESIMPULAN}

Pendapatan yang diperoleh

peternak sapi yang menggunakan kawin alam di Desa Tempok sebesar Rp.521.072.900 dengan rata-rata penerimaan setiap peternak adalah Rp.17.369.096,67/tahun/peternak, dan untuk pendapatan peternak sapi yang menggunakan IB sebesar Rp.418.414.600 dengan rata-rata pendapatan setiap peternak adalah Rp.13.947.153,33/tahun/peternak.Namun demikian perbedaan pendapatan ini secara statistik tidak menunjukkan perbedaan yang signifikan.

Faktor - faktor yang mempengaruhi pendapatan peternak sapi yang menggunakan IB yaitu biaya pakan, biaya obat-obatan, dan biaya tenaga kerja. Pendapatan peternak sapi yang menggunakan kawin alam dipengaruhi oleh biaya pakan, biaya obat, biaya tenaga kerja dan sewa pejantan.

\section{DAFTAR PUSTAKA}

Aiba, A., J.C. Loing, B. Rorimpandey dan L.S. Kalangi. 2018. Analisis peternak usaha sapi potong di Kecamatan Weda Selatan Kabupaten Halmahera Tengah. Jurnal Zootek 38 (1):149-159
Dewandini, R.S. Kuning. Motivasi petani dalam budidaya tanaman mendong (fimbristylis globulosa) di Kecamatan Minggir Kabupaten Sleman. Skripsi. Program Studi Penyuluhan dan Komunikasi Pertanian. Fakultas Pertanian. Universitas Sebelas Maret. Surakarta.

Gupito, R.W., Irham dan L.R. Waluyati. 2014. Analisis faktor-faktor yang mempengaruhi usaha tani sorgun di Kabupaten Gunug Kidul. Jurnal Argo Ekonomi 24 (1):66-75

Hermanto. 1996. Analisa Usahatani. Bina Aksara. Jakarta

Hastuti, D., S. Nurtini, R. Widiawati. 2008. Kajian sosial ekonomi pelaksanaan inseminasi buatan sapi potong di Kabupaten Kebumen Mendiagro. Jurnal Ilmu-Ilmu Pertanian 4(2):1-12

Hasibuan, M.I.A., M. Ginting dan Emalisa. 2014. Analisis usaha ternak sapi potong. Jurnal Sosial Ekonomi Dan Agribisnis 3(3): 1-3

Kiswanto., A. Prabowo dan Widyantoro. 2004. Transformasi struktur usaha penggemukan sapi potong di Lampung Tengah. Sistem dan Kelembagaan Usahatani Tanaman Ternak. Prosiding Seminar. Balai Penelitian dan Pengembangan Pertanian Departemen Pertanian, Januari, 2004. P.111-121

Monintja M.Y., F.S. Oley, B.F. Sondakh dan F.N.S, Oroh. 2015. Analisis kuntungan peternak sapi peranakan ongole yang menggunakan inseminasi buatan di Kecamatan 
Tompaso Barat. Jurnal Zootek 35(2):201-209

Nurcholida, Sodiq dan K. Muatip. 2013. Kinerja usaha peternakan sapi potong sebelum dan setelah mengikuti program sarjana membangun desa (SMD) periode 2008-2012. Jurnal Ilmiah Peternakan 1(3):1183-1191

Otampi R.S., F.H. Elly, M.A.V. Manese dan G.D. Lenzun. 2017. Pengaruh harga pakan dan upah tenaga kerja terhadap usaha ternak sapi potong petani peternak di Desa Wineruh Kecamatan Likupang Timur Kabupaten Minahasa Utara. Jurnal Zootek 37(2):483-495

Rochaeni, S., E. Daris dan Hanafi. 2014. Analisis faktor-faktor yang mempengarui permintaan tempe di Kelurahan Jurang Mangu Timur Pondok Aren Tangerang Selatan. Jurnal Agribisnis 8(1):1-14

Sugiarto dan Siregar. 1998. Dampak pelaksanaan inseminasi buatan (IB) terhadap peningkatan pendapatan peternak sapi perah di daerah Jawa Barat. Jurnal Ilmu Ternak dan Veteriner 4(1):3-4

Sugiyono. 2006. Statistik Penelitian. Alfa Beta. Bandung

Soelistyo, H. 2011. Pelanggaran Hak Cipta dan Etika. Kanisius. Yogyakarta

Sirajudin S.N., V.S. Lestari, N.S. Fadliah. 2013. Perbandingan peternak sapi bali yang melakukan program inseminasi buatan dan tidak melakukan program inseminasi buatan di Kecamatan Soppeng Riaja Kabupaten Barru. Jurnal Ilmu Ternak 13(1):1-13

Siswandari, G.A., R.H. Ismono, dan H. Santoso. 2013. Pengaruh sertifikasi tanah UKM terhadap pendapatan rumah tangga peternak pengemukan sapi di Desa Rajabasa Lama 1 Kecamatan Labuhan Ratu Kabupaten Lampung Timur. Jurnal Ilmu-Ilmu Agribisnis 1(4):319-325 